\title{
First record of Dasysyrphus tricinctus (Fallén, 1817) (Diptera: Syrphidae) from Iran
}

\author{
Farzaneh Kazerani ${ }^{1}$, Ali Asghar Talebi ${ }^{1^{*}}$ and Ebrahim Gilasian ${ }^{2}$ \\ 1 Tarbiat Modares University, Faculty of Agriculture, Department of Entomology, P.O.Box: 14115-336, Tehran, I.R.Iran. \\ 2 Iranian Research Institute of Plant Protection, Insect Taxonomy Research Department, P.O.Box: 1454-19395, Tehran, Iran. \\ * Corresponding author. E-mail: talebia@modares.ac.ir
}

\begin{abstract}
The genus Dasysyrphus Enderlein, 1938 (Diptera: Syrphidae) was studied in Northern Iran. Two species, $D$. albostriatus (Fallen, 1817) and D. tricinctus (Fallen, 1817) were identified. D. tricinctus is a new record for the fauna of Iran. Diagnostic characters and geographical distribution of $D$. tricinctus are briefly discussed. Supplementary photographs of the species are provided.
\end{abstract}

The family Syrphidae (Diptera: Cyclorrhapha), commonly called hover flies or flower flies, comprise about 6000 described species worldwide (Thompson and Rotheray 1998). Up to date, about 40 species of the genus Dasysyrphus Enderlein, 1938 have been described (Huo et al. 2005). In the Palaearctic region, 19 species are listed by Peck (1988), but the taxonomy of several taxa are not well elucidated (Reemer 2002). Three species of this genus, D. albostriatus (Fallén, 1817), D. pinastri (Meigen 1822 ) and $D$. tricinctus (Fallén 1817), have been recorded for the Turkish fauna (Saribiyik and Hasbenli 1997) and 12 species have been reported from China (Huo et al. 2005). Thus far, two species of the genus Dasysyrphus have been reported from Iran: D. albostriatus (Fallen 1817) and D. eggeri (Schiner 1862) (Gharali and Gilasian 2002; Dusti 2006). Larvae of Dasysyrphus species feed on aphids (Rotheray 1993). The objective of this study was to determine the occurrence of Dasysyrphus species in the Northern region of Iran.

Material for this study was collected from different habitats of Northern Iran (Figure 1) using malaise traps with $75 \%$ ethanol as the killing and preserving agent. Samples were collected from March to November 2010 and 2011. The specimens were extracted from the malaise traps and sorted weekly. Individuals were then treated with $100 \%$ ethanol for 5 minutes followed by hexamethyldisilazane (HMDS) for $30 \mathrm{~min}$ and finally placed on a glass plate for drying. The dried specimens were then labeled. Morphological terminology follows Van Veen (2004) and Stubbs and Falk (1983). Vouchers are deposited at the insect collection of the Department of Entomology, Tarbiat Modares University, Tehran.

Two species of the genus Dasysyrphus were collected and identified from the study area, including one previously reported species D. albostriatus (Fallén, 1817) (Dousti and Hayat 2006), and one newly recorded species $D$. tricinctus (Fallén, 1817).

\section{Dasysyrphus albostriatus (Fallén, 1817)}

Synonyms: Dasysyrphus confusus (Egger, 1860), Scaeva

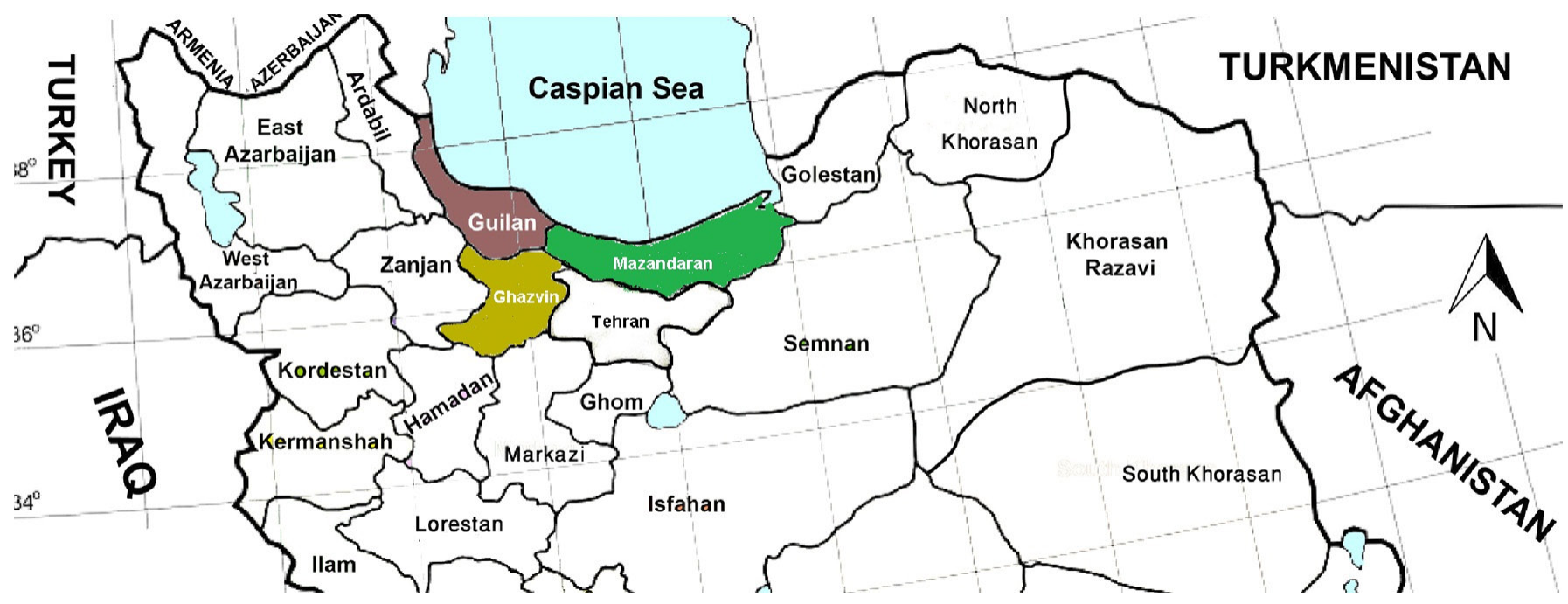

FIGURE 1. Iranian provinces where Dasysyrphus species were collected. 
albostriatus Fallén, 1817, Syrphus confusus Egger, 1860

Material examined: IRAN: Mazandaran Province, Noor, Jurband ( $36^{\circ} 26.259^{\prime} \mathrm{N}, 052$ 07.225' E), 275 m, (7 \& 5ㅇ), 13. IV. 2011; IRAN: Mazandaran Province, Noor ( $36^{\circ}$ 34.883’ N, 052 02.763' E), -14 m, (1ठ), 8. X. 2011; IRAN: Guilan Province, Rudsar, Orkom (36 45'739" N, 50¹8'198" E), 1201 m, 25-X-2010, 1ㅇ; IRAN: Ghazvin Province, Zereshk road (36 25.656’ N, 050 06.615’ E), 1997m, (1○), 27. VIII. 2011; leg. M. Kheirandish.

General distribution: Ireland eastwards through central and southern Europe (Italy, the former Yugoslavia) to Crete (Speight 2006), Turkey (Sarıbıyı 1997); north Africa (Speight 2006); Japan (Pan et al 2010); Iran (Gharali and Gilasian 2002).

\section{Dasysyrphus tricinctus (Fallén, 1817) (Figure 2)}

Synonyms: Conosyrphus okunii Matsumura, 1918, Lasiophthicus coronatus Rondani, 1857, Scaeva tricincta Fallen, 1817

Material examined: IRAN: Mazandaran Province, Jurband ( $36^{\circ} 26.259^{\prime} \mathrm{N}, 052$ 07.225' E), 275 m, (1今), 13. IV. 2011; leg. A. Nadimi (Figure 1).

General distribution: Britain, Denmark, Finland, France, Germany, Ireland, Japan, Luxembourg, Mongolia, Netherlands, Norway, Spain, Sweden (Ball and Morris 2000), Turkey (Sarıbıyı 2008). New record from Iran.

Diagnosis: Head: Frons black; face with black median longitudinal strip that reaches the base of the antenna; mouth edge black; antennae short and black (Figure 2E). Thorax: Scutum shiny black, scutellum yellow with long yellow hairs (Figure 2D); wing with dark stigma (Figure 2B); legs mostly yellow, the basal half of femora black. Abdomen: Tergite II with two yellow small spots, tergite III black with two yellow wide bands, tergite IV black with two yellow bands narrower than those of third tergite, tergite $\mathrm{V}$ black (Figure 2D); sternits black, $1^{\text {st }}$ sternit with two yellow spots, sternite II two yellow bars and a yellow band, sternite III with two yellow small spots and with a yellow band narrower than those of $2^{\text {nd }}$ sternite, sternits IV $+\mathrm{V}$ black (Figure 2C).

Male genitalia: Surstylus moderately long, uniformly tapering, directed posteroventrad, not distinctly flattened posteriorly; aedeagal base tremendously expanded dorsally (Figure 2F).

On the basis of characteristics of the male genitalia, Vockeroth (1969) distinguished four species groups in the genus Dasysyrphus: albostriatus species group, the pinastri species group, the tricinctus species group and the venustus species group. Two groups have representatives in Iran. Dasysyrphus albostriatus and D. eggeri (Schiner 1862) belong to albostriatus species group and $D$. tricinctus belong to tricinctus species group.

Dasysyrphus tricinctus is reported from the entire Balkan Peninsula and occurs mainly in forests. It has only been collected at higher elevations in Macedonia (Krpac et al. 2009). Rotheray (1994) reports that larvae are frequent predators of aphids on Acer pseudoplatanus. Adults are usually found in or near woodlands, along edges and tracksides, where they visit a wide range of flowers (Ball and Morris 2000).
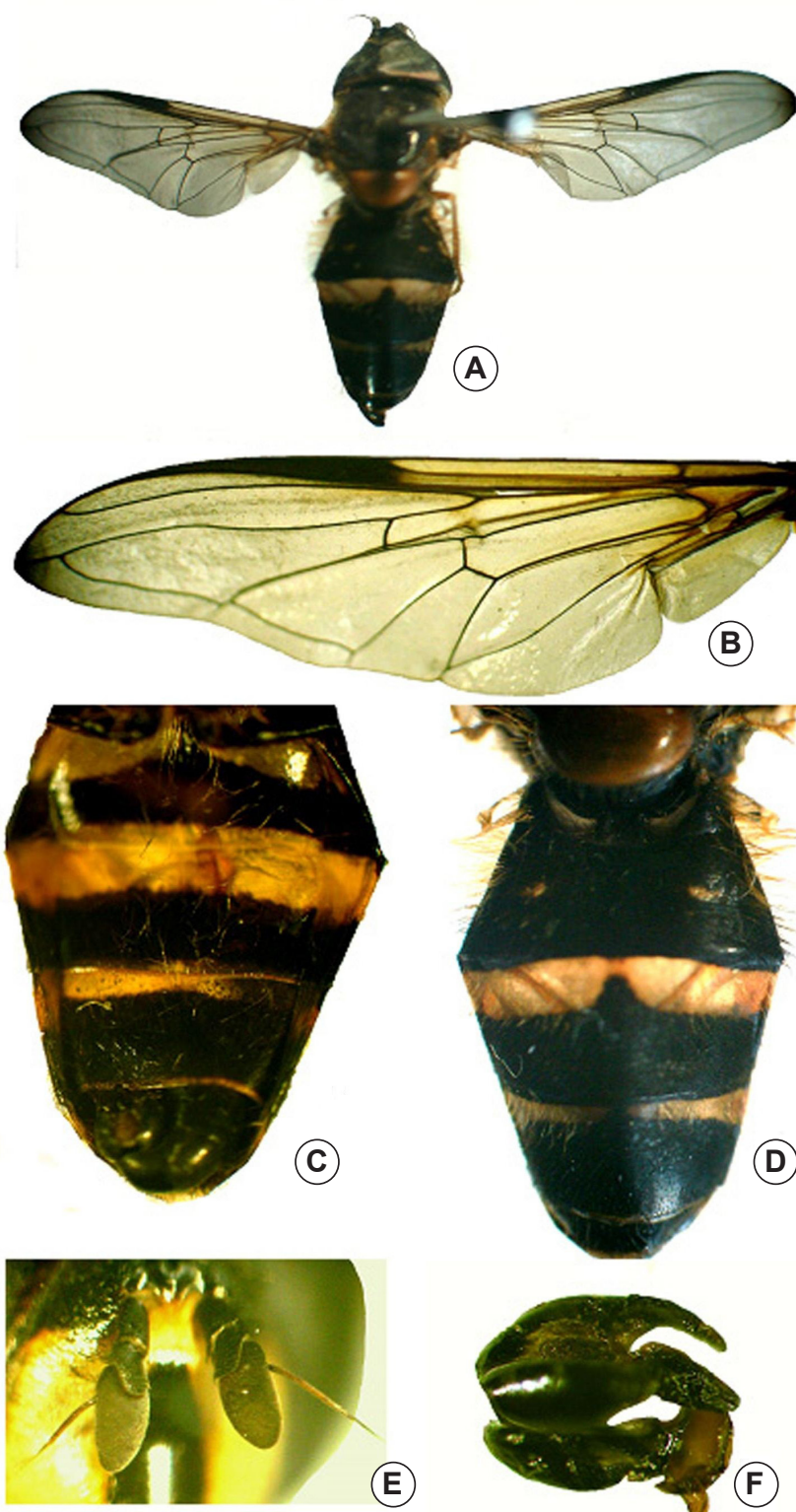

(E)

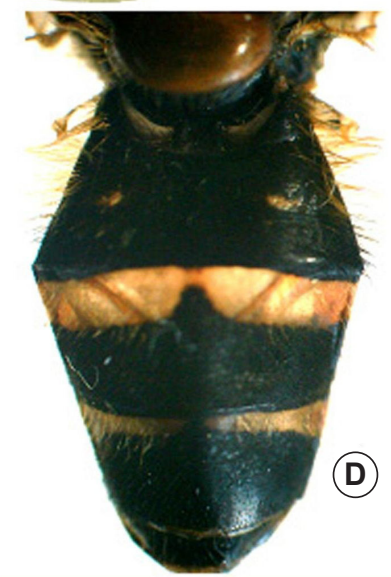

(B)

Figure 2. Dasysyrphus tricinctus, male; A) Adult; B) Ventral view of abdomen; C) Dorsal view of Abdomen; D) Antenna; E) Wing venation; F) Genitalia.

ACKNowledgments: We would like to thank the Department of Entomology, Tarbiat Modares University for providing financial support for this research. Our cordial thanks are expressed to Dr.W. V. Steenis and the editor, Matthew Smart for helpful suggestions on the earlier version of the manuscript. We also thank Mr. A. Nadimi and M. Kheyrandish (the PhD students of Tarbiat Modares University, Tehran, Iran) for collection of the specimens which were studied in this paper.

\section{Literature Cited}

Ball, S.G. and R.K.A. Morris. 2000. Provisional atlas of British hoverflies. Huntingdon: Centre for Ecology and Hydrology. 167p.

Dusti, A.F. and R. Hayat. 2006. A Catalogue of the Syrphidae (Insecta: Diptera) of Iran. Journal of the Entomological Research Society 8(3): 5-38.

Gharali, B. and E. Gilasian. 2002. New record of Dasysyrphus eggeri (Shiner, 1862) (Dip.: Syrphidae) from Iran. Journal of Entomological Society of Iran 22(1): 79-80.

Huo, K.K., H.J. Zhang and Z.M. Zheng. 2005. Two new species of Dasysyrphus (Diptera, Syrphidae) from China, with a key to species from China. Acta Zootaxonomica Sinica 30(4): 847-851.

Krpac, V.T., A.Vujic, S. Smiljka, S. Radenkovic and S. Lazarevska. 2009. Revision of the Genus Dasysyrphus Enderlein, 1938 (Diptera: Syrphidae) in the fauna of Macedonia. Kragujevac Journal of Science 31: 103-108. 
Pan, Z., B. Wang and K. Huo. 2010. A new species of genus Dasysyrphus Enderlein (Diptera, Syrphidae) from China. Journal of Northeast Forestry University 38(11): 133-134.

Peck, L.V. 1988. Family Syrphidae. In A. Soos and J. Papp (ed.). Catalogue of Palearctic Diptera. Syrphidae - Conopidae. Amsterdam: Elsevier. $363 \mathrm{p}$.

Reemer, M. 2002. Lena's wimperzweefvlieg Dasysyrphus Lenensis in Nederland (Diptera: Syrphidae). Nederlandse Faunistische Mededelingen 17: 13-18.

Rotheray, G. E. 1993. Color guide to hoverfly larvae. Dipterist Digest 9:1156.

Sarıbıyık, S. and A. Hasbenli. 1997. New Records for fauna of Turkish Syrphidae, (Diptera). Turkish Journal of Entomology 21(3): 225-232.

Sarıbıyık, S. 2008. Dasysyrphus tricinctus (Fallen, 1817) Turu İle İlgili Bazi Ekolojic Notlar (Diptera: Syrphidae). Kastamonu Eğitim Dergisi 16(2) 577-580.

Speight, M. C. D. 2006. Species accounts of European Syrphidae (Diptera); vol. 44, 235 pp. In M.C.D. Speight, E. Castella, J.P. Sarthou and C. Monteil (ed.): Syrph the Net, the database of European Syrphidae. Dublin: Syrph the Net publications.
Thompson, F.C. 2006. Biosystematic Database of World Diptera. Version 7.5. Electronic Database accessible at http://www.diptera.org/ biosys.htm. Captured on 20 February 2012.

Thompson, F.C. and G.E. Rotheray. 1998. Family Syrphidae; p. 81-139 In Papp, L. and B.Darvas, (ed.). Contributions to a manual of Palaearctic Diptera (with special reference to flies of economic importance. Vol 3. Budapest: Science Herald.

Van Veen, M.P. 2004. Hover flies of Northwest Europe: identification keys to the Syrphidae. Utrecht: KNNV Publishing. 254p.

Vockeroth, J.R. 1969. A revision of the genera of the Syrphini (Diptera: Syrphidae). Memoirs of the Entomological Society of Canada 62: 1-176.

RECEIVED: May 2012

ACCEPTED: June 2012

Published online: August 2012

EDITORIAL RESPONSIBILITY: Matthew Smart 